\title{
Social Media Adoption in Adult Education - Administrators' Experience
}

\author{
Jolita Šliogerienė, Giedrė Valūnaitė Oleškevičienė \\ Mykolas Romeris University \\ Ateities str. 20, LT-08303 Vilnius, Lithuania \\ Julia Fotheringham \\ Edinburgh Napier University \\ E-mail: J.Fotheringham@napier.ac.uk
}

Kirsty J Palfreyman

ICS Learn

Breckenridge House, 274 Sauchiehall Street,

Glasgow G2 $3 E H$

doi:10.13165/VPA-14-13-4-11

\begin{abstract}
The rapid development of social media poses a multitude of considerations on this technology adoption. The emphasis in literature is put mainly on student or teacher perspective and less emphasis is dedicated upon administrators who also represent an important group of stakeholders. The aim of the study is to examine the phenomenon of potential educational use of social media at the public institutions of adult education based on administrators' lived experience, taking into account how administrative factor influences social media adoption in education. The findings reveal that admitting the advantages of social media use, administrators also identify certain problematic areas and have cautious attitudes towards social media in education.
\end{abstract}

Keywords: social media, administrator's attitude, phenomenological approach, public institutions of education, educational administrators.

Raktiniai žodžiai: socialinès medijos, administratoriu požiūris, fenomenologinès prieigos, viešosios švietimo ịstaigos, švietimo ìstaigu administratoriai. 


\section{Introduction}

The drive towards educational organisation's adoption of social media reflects a combination of external pressures and internal drivers, all of which may be underpinned by a desire to enhance learning and teaching and to widen student participation [9]. The reputation of adult education institutions are no longer solely determined by international ranking systems and market share, but also by the quality of their interactions with students, employers, the local community and society at large. It is stated that faculty culture and its sources of prestige are particularly related to institutional outcomes and societal needs [9].

The objective of this paper is to further analyse the views held by educational administrators on the uptake of social media in their professional institute.

For this study, the authors adopted Kaplan and Haenlein [18] definition of social media as "a group of Internet-based applications that build on the ideological and technological foundations of Web 2.0, which allows the creation and exchange of user-generated content". Different definitions of social media emphasise slightly different technical features, channels and affordances. For institutions, which primary focus is education, Kaplan and Haenlein's [18] definition places sufficient priority on the potential for interaction and co-creation of content and knowledge. It has long been recognized that traditional media has the potential to reach broad global audiences; however, social media can reach the same audiences in a faster, more cost effective manner. Furthermore, because of the ease to use software that characterises most social media applications, special skills or expertise are not necessarily required. To engage with social media, all that participants require is some sort of ICT device (such as a computer, laptop or smartphone) and a broadband connection with which to access to the internet.

Representatives from the student body, teaching body and administration of public institutions were interviewed to capture the perceptions and beliefs of the use of social media in adult education.

For the purpose of this paper, a phenomenological approach was employed to analyse the data that was captured by the administrators. As articulated by Laurillard $[19$, p. 63], a top down approach is generally required to allow for new practice and technology to be really harnessed into institutions which can feel lethargic in their process change. So many factors for success surround appropriate resources, finances and attitudes being offered by the institutions' principal personnel.

\subsection{Strategy development - the significance of values}

The rapid development of social media and its impact on how, where and when learning takes place suggests that this technology adoption represents a transformatory innovation in educational services rather than just innovation in the use of IT technology [25]. Indeed, Marshall [24, p. 180] observes a trend in the 
literature towards studies that explore the implementation of e-learning in terms of multi-perspective approach. Facer and Sandford [11] propose a series of four of guiding principles in which to frame futuristic discussions about education and strategic approaches to embedding technology. These principles assert that "the future is not determined by its technologies" [11, p. 81], but rather values and politics are an inextricable part of discussions about possibilities for the future of education.

The emphasis in many empirical technology adoption studies in the literature, some of which are described below, is put upon teacher and/or student perspectives, with far less emphasis on the attitudes and beliefs which inform approaches being taken by those in the category that for this study the authors have called 'administrators'. Yet according to Chesterton et al. (2008) (cited in Marshall, 2012) [24, p. 181], the contribution made by administrators, such as educational technologists and learning designers to the successful implementation and adoption of e-learning, "cannot be underestimated" [24, p. 181]. Given the complexity of technology strategy development, failure to explore the diversity of attitudes and values of all stakeholders, including academics, administrators and students involved in the adoption of technology, are likely to result in an incomplete picture of any implementation study.

Johnson and Smyth [16, p. 218] described a series of strategy workshops that were part of a programme (Taking forward change in technology-enhanced education) involving around $20 \mathrm{UK}$ higher education (HE) institutions. The workshops were intended to foster communications and to expose the diversity of values amongst stakeholders in the development of HE institutional learning technology strategy. Consensus and contradictions amongst the stakeholder groups are discussed in the mentioned study, and Johnson and Smyth [16] refer to the 'nascent tension' [16, p. 217] amongst the various stakeholders, which was revealed during carefully designed learning activities. For example, in responding to questions about their perceived vision of the future with regards to technology use, academics expressed the desire for responsive and supportive IT departments which ensured that as new developments and applications become available, e.g., mobile apps, these should be "ready to use". Yet responses from IT professionals and other administrators suggested uneasiness about the conflicting expectations that other stakeholders had of their departments. On the one hand, managers favoured using technology to build institutional identity and efficient business process, both of which require an effective technological infrastructure, while on the other hand, academics and some students express the need for greater flexibility, autonomy, personalisation and the opportunity to engage with external systems. This potentially leaves learning technologists with a struggle to reconcile the need to maintain expertise and institutional reputation in the development and support of closed unified systems, such as Virtual Learning Environments (VLE) as well as the requirement to adapt to and support emerging open technologies. 


\subsection{Technology adoption - theoretical frameworks}

Attitudes and values are regularly identified in empirical studies as key factors in the uptake and adoption of technologies. But we are reminded by Gergen and Roblyer's study [13] that although attitudes and beliefs certainly impact the adoption of technology, such perspectives may be based on misconceptions about the quality or effectiveness of tools and a lack of understanding about the ways in which social media can be deployed to support particular approaches to learning and teaching [26].

Continuing with the significance of attitudes, Dooley and Murphrey [9] observe that although available learning technologies have changed, attitudes towards those technologies have remained fairly constant over time. Of particular note for this paper is their observation that there is a great deal of similarity of attitudes towards the adoption of technology amongst administrators, faculty and support units [9]. They assert that in order to increase technology adoption, three areas require particular attention: administrative support, training and incentives. Furthermore, they emphasise the importance of having policies in place to establish and support 'institutional capacity' [9, p. 366] to engage with educational technologies.

Stockman and Truyen [26] propose a theoretical framework which identifies factors that influence the successful implementation of educational technology and the impact that these factors have upon teacher uptake and deployment of these tools in their teaching. The inner factors are intrinsic to the teacher (beliefs, competence and confidence), whereas the outer factors (time, technology, community and support) are variable and context dependent [26]. The outer factors may be of particular significance to administrators, who are the focus of this paper. One of the drawbacks of this framework is its exclusive focus on teachers as technology adopters, but McGuire's [23] literature review of academic participation in online distance education notes that lack of technical support and lack of time to develop and maintain course material are consistently noted by academics as barriers to technology adoption, and these are topics which directly impact upon administrators. Furthermore, Dillenbourg [8] notes that although adequate funding is not a sufficient condition for positive engagement with technology enhanced learning, it is, however, a necessary condition.

Davis's [6] Technology Acceptance Model (TAM) features two constructs, 'perceived usefulness' (PU) and 'perceived ease of use', as predictors of a far wider category of user acceptance which may be useful in analysing interviews from students, academics, as well as administrators. Lee [21] extends Davis's [6] Technology Acceptance Model (TAM) to investigate how the availability of external resources (support, training and equipment accessibility) impact upon student engagement with technology. These external resources appear to be consistent with several of Stockman and Truyen's [26] 'external factors' noted above. By understanding how these factors affect student acceptance and engagement with technologies, it may be possible for senior managers and administrators to formulate 
adoption strategies which are discussed in the research and which facilitate successful uptake by teachers, administrators and students.

\section{Aims and objectives}

The aim of this phenomenological study is to describe and analyze the phenomenon of potential educational use of social media by administrators at the public institutions of adult education based on administrators' lived experience. Thus, the research was carried out in public institutions of adult education. The main research question is focused on how administrators perceive and name their experience connected to educational use of social media in their institutions. The objectives of the research are: 1) to produce a literature review, which captures the current context of social media use in adult education, and 2) to analyze research participant insight, regarding the views on social media use in adult education environments.

\section{Methodology of the research}

Van Manen's [29] insights about the connectedness of phenomenology and pedagogy justify the phenomenological approach to this research. Phenomenology is perceived not as a pure description, but as an interpretation of lived experiences related to the phenomenon.

Semi-structured interviews were used for empirical data collection. In-depth interviews were conducted with administrators from public institutions providing education: Edinburgh Napier University, International Correspondence School (ICS) and Mykolas Romeris University (MRU). Four in-depth interviews with administrators were carried out in each institution, with the total number of 12 interviews. The interviews were aimed to get a snapshot of the phenomenon of potential educational use of social media by administrators at the public institutions of adult education across the institutions and countries where the research was carried out; comparison across the institutions was excluded due to the nature of the research - the main focus on the phenomenon, and the different nature of institutions: universities and the centre of adult education. The method of criterionbased sampling was applied. Respondents have been selected according to the following criteria: nature of work (specialists who work with both staff and students and are well-acquainted with the needs of both groups) and experience of using social media (at least three years of job experience using social media).

During the interviews, open questions were related to the explicit nature of the use of social media either for work or for studies. The following aspects have been addressed:

- Background of the institution;

- Social media currently adopted within the institution; 
- Definition of social media and its use (personal and professional);

- Impact of social media on work and learning environments;

- Attitudes towards social media in education (culture, future perspectives, values, perceived attitudes of students, teachers and administrators);

- Institutional strategy and support to using social media in teaching and learning.

\section{Research findings}

Empirical research data was processed according to the phenomenological data analysis steps establish by Moustakas [23]. First, the data was preliminary overviewed and then the meaningful statements, sentences or extracts (parts of the sentences), which contained essential information about the experience of the research participants, were highlighted. The next stage included organizing the highlighted statements into sub-themes, thus forming certain clusters of meaning, which later fell into certain themes (topics). Four thematic areas have been distinguished: perceived advantages, perceived problems, social media application support and reservations towards social media.

The thematic area of administrator perceived advantages of social media includes the following: institution promotion, information exchange promotion, communication promoted (see Table 1.).

\section{Table 1. Perceived advantages}

\begin{tabular}{|c|c|c|c|}
\hline Theme & Sub-themes & & Statements \\
\hline \multirow{5}{*}{$\begin{array}{l}\text { Administrator } \\
\text { perceived } \\
\text { advantages of } \\
\text { social media }\end{array}$} & $\begin{array}{l}\text { Institution } \\
\text { promotion }\end{array}$ & $\begin{array}{l}\text { Advertising } \\
\text { opportunities }\end{array}$ & $\begin{array}{l}\text { "Gives more opportunities for advertising } \\
\text { ourselves, to show the positive aspects of } \\
\text { organizing the study process" [MRU3] }\end{array}$ \\
\hline & & $\begin{array}{l}\text { Satisfying } \\
\text { client } \\
\text { expectations }\end{array}$ & $\begin{array}{l}\text { "Students want and expect social } \\
\text { networks to be incorporated" [ICS3] }\end{array}$ \\
\hline & & $\begin{array}{l}\text { Business } \\
\text { benefits }\end{array}$ & $\begin{array}{l}\text { "Business benefits are endless: financial, } \\
\text { e-University, reputation" [ENU1] }\end{array}$ \\
\hline & & $\begin{array}{l}\text { Improving } \\
\text { institution } \\
\text { image }\end{array}$ & $\begin{array}{l}\text { "It increases visibility of institution" } \\
\text { [ICS2] }\end{array}$ \\
\hline & $\begin{array}{l}\text { Information } \\
\text { exchange } \\
\text { promotion }\end{array}$ & $\begin{array}{l}\text { Increased } \\
\text { information } \\
\text { sharing }\end{array}$ & $\begin{array}{l}\text { "It ensures speedy information sharing" } \\
\text { [MRU1] }\end{array}$ \\
\hline
\end{tabular}




\begin{tabular}{|l|l|l|l|}
\hline & & $\begin{array}{l}\text { All senses } \\
\text { involved } \\
\text { [ICS4] }\end{array}$ & $\begin{array}{l}\text { "More visuality, all senses into play" } \\
\text { [ENU3] }\end{array}$ \\
\hline & $\begin{array}{l}\text { Communi- } \\
\text { cation } \\
\text { promoted }\end{array}$ & $\begin{array}{l}\text { Enabled } \\
\text { communi- } \\
\text { cation }\end{array}$ & $\begin{array}{l}\text { "Communication is mass, fast and easy" } \\
\text { [ENU1] }\end{array}$ \\
\hline & $\begin{array}{l}\text { Student } \\
\text { feedback } \\
\text { collection }\end{array}$ & $\begin{array}{l}\text { "Using social media for collecting student } \\
\text { feedback would demo the most important } \\
\text { issues" [MRU2] }\end{array}$ \\
\hline
\end{tabular}

The first sub-theme of institution promotion is closely tied with advertising opportunities, and improvement of institution image, as administrators say, "gives more opportunities for advertising ourselves, increases visibility of institution". The information exchange and promotion includes aspects, such as speed of sharing information and independence of time and place. Communication promotion reveals that due to the use of social media communication becomes more direct, fast and easy.

Table 2. Perceived problems

\begin{tabular}{|l|l|l|l|}
\hline \multicolumn{1}{|c|}{ Theme } & Sub-themes & & \multicolumn{1}{c|}{ Statements } \\
\hline $\begin{array}{l}\text { Administrator } \\
\text { perceived } \\
\text { issues }\end{array}$ & $\begin{array}{l}\text { Time } \\
\text { consumption }\end{array}$ & $\begin{array}{l}\text { Time for } \\
\text { managing } \\
\text { social media } \\
\text { activities }\end{array}$ & $\begin{array}{l}\text { "More time for managing the relationships } \\
\text { and the communication social media } \\
\text { induce" [MRU4] }\end{array}$ \\
\hline & $\begin{array}{l}\text { Time for } \\
\text { mastering } \\
\text { social media } \\
\text { staff and } \\
\text { technology } \\
\text { resources }\end{array}$ & $\begin{array}{l}\text { Necessity for } \\
\text { more staff } \\
\text { resources }\end{array}$ & $\begin{array}{l}\text { "It takes time to take social media into } \\
\text { use" [ICS1] }\end{array}$ \\
\hline & [ENU4]
\end{tabular}




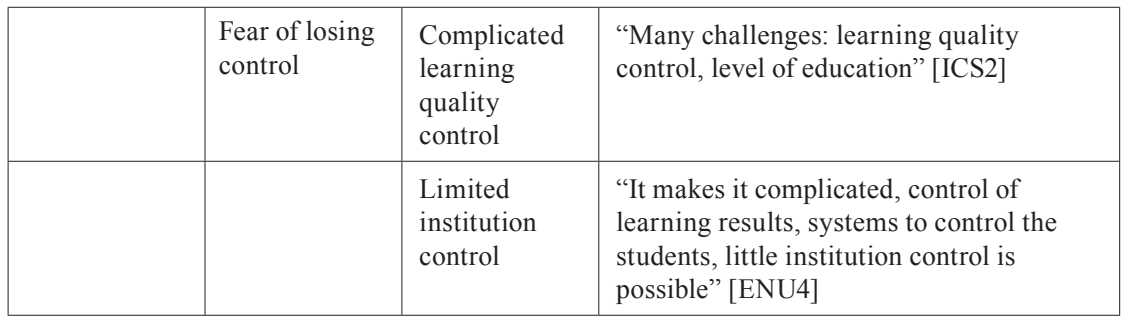

The administrator perceived problems include the following: time consumption, demand for staff and technology resources, requirement for training, fear of loss of control (see Table 2).

Administrators point out that engaging with social media takes additional time as well time for mastering its use. Administrators also mention the necessity to employ more staff to support social media use and to make the technologies accessible. In addition, they see the necessity for training staff, admitting that "teachers need more guidance considering the use of social media". Another issue administrators name is fear of losing control. It seems that administrators are concerned about the way social media influences the teaching/learning process, as "it makes it complicated, control of learning results, systems to control the students, little institution control is possible".

Table 3. Social media application support

\begin{tabular}{|l|l|l|l|}
\hline \multicolumn{1}{|c|}{ Theme } & Sub-themes & & \multicolumn{1}{c|}{ Statements } \\
\hline $\begin{array}{l}\text { Institution } \\
\text { support }\end{array}$ & $\begin{array}{l}\text { Infrastructure } \\
\text { development }\end{array}$ & $\begin{array}{l}\text { Institution } \\
\text { provided } \\
\text { infrastructure }\end{array}$ & $\begin{array}{l}\text { "The institution provides an infrastructure } \\
\text { on which the teaching staff can make } \\
\text { available/choose social media-based } \\
\text { services to be used for teaching/learning" } \\
\text { [MRU3] }\end{array}$ \\
\hline & $\begin{array}{l}\text { Staff } \\
\text { development }\end{array}$ & $\begin{array}{l}\text { Provided } \\
\text { financial help } \\
\text { training }\end{array}$ & $\begin{array}{l}\text { "University provides financial help for } \\
\text { social media, technical and infrastructure } \\
\text { support" [ICS4] }\end{array}$ \\
\hline & $\begin{array}{l}\text { "University is offering training sessions to } \\
\text { staff” [ENU1], [MRU2] }\end{array}$ \\
\hline & & $\begin{array}{l}\text { "University provides guidance for teaching } \\
\text { staff" [ICS3] }\end{array}$ \\
\hline
\end{tabular}

The theme of institution support contains the main sub-themes displayed in the interviews: infrastructure development, staff development (see Table 3).

Infrastructure development identifies how an institution supports the deployment of social media by providing financial help, technical and overall 
infrastructure improvement. Administrators' comments show that institutions recognize the importance of social media responding in terms of material support. In addition, administrators observe that institutions provide training and guidance for the staff as the main force of promoting social media in the institution.

\section{Table 4. Reservations}

\begin{tabular}{|c|c|c|c|}
\hline Theme & Sub-themes & & Statements \\
\hline \multirow[t]{7}{*}{$\begin{array}{l}\text { Caution } \\
\text { regarding the } \\
\text { potential of } \\
\text { social media }\end{array}$} & $\begin{array}{l}\text { Lack of } \\
\text { recognition of } \\
\text { possibilities of } \\
\text { social media } \\
\text { use }\end{array}$ & $\begin{array}{l}\text { Limited } \\
\text { applicability } \\
\text { for teaching/ } \\
\text { learning }\end{array}$ & $\begin{array}{l}\text { "Social media does not have a place in } \\
\text { teaching and learning" [ENU4] }\end{array}$ \\
\hline & & $\begin{array}{l}\text { Unconsidered } \\
\text { business } \\
\text { benefits }\end{array}$ & $\begin{array}{l}\text { "Have not considered any business } \\
\text { benefits" [MRU2] }\end{array}$ \\
\hline & & $\begin{array}{l}\text { Lack of } \\
\text { readiness to } \\
\text { use social } \\
\text { media }\end{array}$ & $\begin{array}{l}\text { "Not yet ready to incorporate social } \\
\text { media" [ICS1] }\end{array}$ \\
\hline & $\begin{array}{l}\text { Lack of } \\
\text { recognition of } \\
\text { possibilities } \\
\text { of staff and } \\
\text { students }\end{array}$ & $\begin{array}{l}\text { Imposed age } \\
\text { limitations }\end{array}$ & $\begin{array}{l}\text { "Harder for staff to use social media due } \\
\text { to their age" [ICS4] }\end{array}$ \\
\hline & & $\begin{array}{l}\text { Students' } \\
\text { knowledge not } \\
\text { appreciated }\end{array}$ & $\begin{array}{l}\text { "Students don't always know how to use } \\
\text { social networks" [MRU3] }\end{array}$ \\
\hline & $\begin{array}{l}\text { Lack of } \\
\text { recognition } \\
\text { validity of } \\
\text { feedback }\end{array}$ & $\begin{array}{l}\text { Unstructured } \\
\text { feedback }\end{array}$ & $\begin{array}{l}\text { "Using social media for collecting } \\
\text { feedback would be unstructured and not } \\
\text { address priorities" [ENU2] }\end{array}$ \\
\hline & & $\begin{array}{l}\text { Dishonest } \\
\text { feedback }\end{array}$ & "It would not be honest feedback" [ICS3] \\
\hline
\end{tabular}

The theme of caution regarding the potential of social media reveals the existence of reservations amongst administrators' views and discloses the fact that different attitudes pertain to social media use in different educational institutions. It contains the following sub-themes: lack of recognition of possibilities of social media use, lack of recognition of possibilities of staff and students, lack of recognition validity of feedback (see Table 4).

Caution regarding the use of social media includes attitudes, such as "social media does not have a place in teaching and learning", as well as unconsidered business benefits and lack of readiness to use social media. Another sub-theme is 
the lack of recognition of the possibilities for social media adoption amongst staff and students, as administrators reveal their controversial attitudes concerning the influence of age and abilities upon the likelihood of social media use. The subtheme of lack of recognition of validity of feedback discloses administrators' doubt on feedback credibility. In this theme, administrators reveal some fundamental suspicions about the use of social media in the learning and teaching process.

\section{Discussion on research findings - towards social media use}

The thematic areas of perceived advantages and reservations give grounds for recognizing one of the key findings of the present study which is the variety of attitudes and the existence of different belief systems amongst administrators. This is consistent with the literature where studies, such as the programme reported upon by Johnson and Smyth [16], emphasise the multitude of perspectives associated with the use of technology in education. The belief system has been proved to be an important factor in social media adoption process (Facer and Sandford, 2010) [11]. Beliefs are one of the inner factors important for social media adoption. The research reveals that administrators admit the advantages of social media use; however, at the same time, there is some reluctance to consider the benefits of social media use ("have not considered any business benefits") or postponed readiness ("not yet ready to incorporate social media").

Another concern, which the present study identifies, is related to the factor of social media adoption and the competence or knowledge connected to social media use. Even if the attitudes are positive, the actual technical and conceptual facts and skills are vital for using technology [26]. Administrators point out the necessity for staff development, training and guidance, although they admit that the process requires resources, such as employing special staff to provide support.

In the thematic area of the perceived problems of using social media, information literacy stands out. The connection between the abundant use of social media for sharing information and the increasing amounts of time spent engaging with social media point to the key issue of developing the necessary skills of information literacy. The research participants identify the problems of processing information obtained from social media. According to the definition of information literacy provided by American Library Association [1], information literacy is a set of abilities requiring individuals to recognize when information is needed and have the ability to locate, evaluate and use effectively the needed information. Information literacy is becoming increasingly important and incorporation of information literacy across curricula in the educational institutions becomes essential and requires the effort of the faculty and administrators.

Another issue arises due to the inherent democratic nature of social media. As Bauman [2] points out, the society is becoming more pluralistic, differentiated and mosaic. Democracy without any visible centre manifests itself in the mosaic social 
media world, as Deleuze [8] states that such a democracy can appear in various places and circumstances, multiple voices of lecturers, teachers and students acquire similar weight. Administrators are concerned about losing control. They express their inclination to control the teaching/learning processes. As it is observed by Foucault [12], educational institutions have ritualized their practice to discipline and control. However, the application of social media acts as a driving force towards democratization of educational processes.

One perceived problem that the administrators identify is recognising that "it takes time to take social media into use". As Stockman and Truyen's [26] study reveals, teachers need time to experiment with technology, apply new technologies and look for the most effective ways of using social media. Another factor is the accessibility of the technology itself. As the administrators admit, "not everyone will have access to technology or software." Unequal access to technology means that social media use in education heavily depends on the availability of technological resources. Support is also an important factor. According to Brill and Park [5], technical support, possibility to get answers to the questions concerning technology use is essential for teachers. Administrators demonstrate their awareness of the necessity of support by admitting that "teachers need more guidance considering the use of social media".

\section{Conclusions}

1. Administrators admit the advantages of social media use, such as institution promotion, which means the possibilities to advertise and satisfy students' as clients' needs and expectations, as well as enhanced information exchange and communication, including receiving instant student feedback.

2. However, administrators identify certain problematic areas and have some cautious attitudes towards social media in education. They are concerned with matters, such as the amount of time necessary both for mastering social media and managing social media activities. Administrators express the need for staff guidance and technology resources, identifying that unequal access to technology exists and admitting that there is the need for institutions to provide support and training for the lecturers.

3. Some cautious attitudes expressed by administrators include doubts whether it is possible to get structured and honest feedback on learning experiences while using social media. Some administrators cannot recognise that social media has a place in teaching and learning and they are also concerned about the staff and students' readiness to use social media. Finally, administrators express fear that widespread adoption of social media may result in loss of control over teaching/ learning processes. These fears could be explained by mosaic nature of social media reality and its inherent democratic nature which allows coexistence of multiple voices of students and lecturers. 
4. Nevertheless, despite their reservations, administrators express their readiness to support the teaching staff by providing the necessary equipment, technical support and endorsement of the need for training in order to enable staff to engage more broadly with social media in teaching.

\section{References}

1. American Library Association. Information Literacy Competency Standards for Higher Education, 1989 [interactive]. [accessed on April, 2013]. <http://www.ala.org/acrl/ standards/informationliteracycompetency>.

2. Bauman, Z. Vartojamas gyvenimas. Vilnius: Apostrofa, 2011.

3. Beetham, H. Review and Scoping Study for a Cross-JISC Learning and Digital Literacies Programme. JISC. 2010 [interactive]. [accessed on November, 2013]. <http://www.jisc. ac.uk/media/documents/programmes/elearning/DigitalLiteraciesReview.pdf $>$.

4. Bennet, S.; Bishop, A.; Dalgarno, B.; Waycott, J.; Kennedy, G. Implementing Web 2.0 Technologies in Higher Education: A Collective Case Study. Computers and Education. 2012, 59(2): 524-534.

5. Brill, J.; Park, Y. Evaluating Online Tutorials for University Faculty, Staff, and Students: The Contribution of Just-in-Time Online Resources to Learning and Performance. International Journal on E-learning. 2011, 10(1): 5-26.

6. Davis, F. Perceived Usefulness, Perceived Ease of Use and User Acceptance of Information Technology. MIS Quarterly. 1989, 13(3): 318-340.

7. Dillenbourg, P. Integrating Technologies into Educational Ecosystems. Distance Education. 2008, 29(2): 127-140.

8. Deleuze, G.; Parnet C. Dialogues. London: The Athlone Press, 1987.

9. Dooley, K.; Murphrey, T. How the Perspectives of Administrators, Faculty, and Support Units Impact the Rate of Distance Education Adoption. Journal of Distance Learning Administration. 2000, 3(4): 363-369 [interactive]. [accessed on November, 2013]. $<$ http://www.westga.edu/ distance/ojdla/winter34/dooley34.html $>$.

10. Duan, Y.; He, Q.; Feng, W.; Li, D.; Fu, Z. A Study on E-learning Take-up Intention from an Innovation Adoption Perspective: A Case in China. Computers and Education. 2010, 55(1): 237-246.

11. Facer, K.; Sandford, R. The Next 25 Years? Future Scenarios and Future Directions for Education and Technology. Journal of Computer Assisted Learning. 2010, 26(1): 74-93.

12. Foucault, M. Disciplinuoti ir bausti: kalejimo gimimas, Vilnius: Baltos lankos, 1998.

13. Gergen, T. D.; Roblyer, M. D. Analyzing Reasons for Non-adoption of Distance Delivery Formats in Occupational Therapy Assistant (OTA) Education. Online Journal of Distance Learning Administration. 2013, 16 (1).

14. Goodyear, P.; Ellis, R. University Students' Approaches to Learning, in Distance Education. Taylor \& Francis, 2008.

15. Hall, R. Towards a Resilient Strategy for Technology-Enhanced Learning. CampusWide Information Systems. 2011, 28(4): 234-249.

15. Johnson, J.; Smyth, K. Diversity, Value and Technology: Exposing Value Pluralism in Institutional Strategy. Campus-Wide Information Systems. 2011, 28(4): 211-230. 
17. Judson, E. How Teachers Integrate Technology and Their Beliefs about Learning: Is There a Connection? Journal of Technology and Teacher Education. 2006, 14: 581-597.

18. Kaplan, A. M.; Haenlein, M. Users of the World, Unite! The Challenges and Opportunities of Social Media. Business Horizons. 2010, 53(1): 59-68.

19. Laurillard, D. Rethinking University Teaching: A Conversation Framework for the Effective Use of Learning Technologies. Routledge, 2001.

20. Lawless, K. A.; Pellegrino, J. W. Professional Development in Integrating Technology into Teaching and Learning: Knowns, Unknowns, and Ways to Pursue Better Questions and Answers. Review of Educational Research. 2007, 77: 575-614.

21. Lee, Y. The Role of Perceived Resources in Online Learning Adoption. Computers \& Education. 2008, 50: 1423-1438.

22. Moustakas, C. Phenomenological Research Methods. Thousand Oaks, CA: Sage Publications, 1994.

23. Maguire, L. Literature Review - Faculty Participation in Online Distance Education: Barriers and Motivators. Online Journal of Distance Learning Administration. 2005, VIII(I).

24. Marshall, S. An Analytic Framework to Support E-learning Strategy Development. Campus-Wide Information Systems. 2012, 29(3): 177-188.

25. Rossier, D.; Crock, M. Embedding E-learning: A New Perspectives on Change and Innovation. International Journal of Learning Technology. 2006, 2(4).

26. Stockman, C.; Truyen, F. The Danger of the Downward Spiral: Teachers and Digital Literacy. Proceedings of the 10th European Conference on e-Learning, Reading: Academic Publishing Ltd., 2011.

27. Van Manen, M. Researching Lived Experience: Human Science for an Action Sensitive Pedagogy. London: The Althouse Press, 1990.

Jolita Šliogerienè, Giedrè Valūnaitė Oleškevičienė, Julia Fotheringham, Kirsty J Palfreyman

\section{Socialinių medijų taikymas suaugusiųjų švietime - administratorių patirtis}

\section{Anotacija}

Socialinių medijų spartus vystymasis kelia daugybę klausimų, susijusių su šių technologijų įsisavinimu. Mokslinèje literatūroje daugiausia dèmesio skiriama studentų ir pedagogų požiūriams ir mažiau švietimo įstaigose dirbantiems administratoriams, kurie atstovauja suinteresuotųjų asmenų grupei. Straipsnio tikslas yra aprašyti administratorių socialinių medijų naudojimo suaugusiųjų švietimo procesuose reiškinį, pagrịstą viešųjų švietimo įstaigų administratorių patirtimi, apžvelgiant, kaip administracinis faktorius veikia socialinių medijų taikymą švietime. Tyrimo duomenys rodo, kad švietimo ịstaigų administratoriai, pripažindami socialinių medijų privalumus, nurodo tam tikras problemines sritis ir išreiškia abejones dèl socialinių medijų naudojimo švietime.

Jolita Šliogeriene - Mykolo Romerio universiteto Politikos ir vadybos fakulteto Filosofijos ir humanistikos instituto profesorè, socialinių mokslų daktarè.

E. paštas: j.sliogeriene@gmail.com 
Giedrè Valūnaite Oleškevičienè - Mykolo Romerio universiteto Politikos ir vadybos Fakulteto Filosofijos ir humanistikos instituto lektoré, socialinių mokslų doktorantè.

E. paštas: gentrygiedre@gmail.com

Julia Fotheringham - Edinburgo Napier universiteto lektorè, atsakinga už akademinę veiklą direktoriaus pavaduotojo biure.

E. paštas: J.Fotheringham@napier.ac.uk

Jolita Šliogeriene, Doctor of Social Sciences, Mykolas Romeris University, Faculty of Politics and Management, Institute of Philosophy and Humanities, Professor.

E-mail: j.sliogeriene@gmail.com

Giedrè Valünaitè Oleškevičiene, Doctoral student of Social Sciences, Mykolas Romeris University, Faculty of Politics and Management, Institute of Philosophy and Humanities, lecturer.

E-mail: gentrygiedre@gmail.com

Julia Fotheringham, Lecturer of Academic Practice at the Office of the Vice Principal of Edinburgh Napier University.

E-mail: J.Fotheringham@napier.ac.uk

Straipsnis įteiktas redakcijai 2014 m. rugsejjo mèn.; recenzuotas; parengtas spausdinti lapkričio mèn. 